\title{
Effect of Plant Growth Regulators on In Vitro Direct Organogenesis of Paulownia tomentosa plant
}

\author{
Zeinab K. Taha and Engy A. Seleem* \\ Agricultural Botany Department, Faculty of Agriculture, Cairo University, 12613, Giza, Egypt \\ *Corresponding author: engy.seleem@agr.cu.edu.eg
}

Received on: 12-4-2021

Accepted on: 2-5-2021

\begin{abstract}
In vitro propagation of P. tomentosa (Thunb.) Steud. was performed in the Tis sue Culture Laboratory of the Department of Agricultural Botany to find out the effect of plant growth regulators (PGRs) on the ability of steminternodes of Paulownia Plant to regenerate direct organs as well as on their morphological characteristics. Paulownia steminternodes obtained from seeds planted in vitro were cultured on Murashige and Skoog (MS) medium with supplements of different combinations of $\alpha$-naphthalene acetic acid (NAA) with Benzy ladenine (BA), and NAA with 2-isopentenyl adenine (2ip). The results showed that the combinations of $0.5 \mathrm{mg} \mathrm{L}^{-1} \mathrm{NAA}$ with $2 \mathrm{mg} \mathrm{L}^{-1} 2 \mathrm{ip}$, as well as $0.5 \mathrm{mg} \mathrm{L}^{-1} \mathrm{NAA}$ with $4 \mathrm{mg} \mathrm{L}^{-1}$ BA gave the highest regeneration percentage, shoot length $(\mathrm{cm})$, shoot fresh and dry weights $(\mathrm{g})$. For root reg eneration, the obtained shoots were excised and cultured on a rooting medium containing half-strength MS salts with different concentrations of indole-3butyric acid (IBA) and NAA (each individually). It was observed that either the concentration of $1.0 \mathrm{mg} \mathrm{L}^{-1} \mathrm{NAA}$ or $2.0 \mathrm{mg}$ $\mathrm{L}^{-1}$ IBA resulted in the highest values of rooted shoots percentage, No. of roots per shoot, average root length $(\mathrm{cm})$, and fresh and dry weights $(\mathrm{g})$.
\end{abstract}

KEYWORDS: Direct organogenesis, growth regulators, morphological characteristics, Paulownia tomentosa, stem internodes.

\section{INTRODUCTION}

Paulownia is a genus belonging to family Paulowniaceae (Scrophulariaceae) indigenous to China and including nowadays over 20 species (ElHomosany and Noor El-Deen,2019). It is a deciduous tree, up to $15 \mathrm{~m}$ tall, with heart-shaped leaves arranged in opposite pairs on the stem. Paulownia is very adaptable and extremely fast-growing under optimum conditions. It is famous for ornamental use, timber production. Also, different plant parts are used in Chinese herbal medicine (Puxeddu et al., 2012; Ben Bahri and Bettaieb, 2013).

Propagation of Paulownia tree can be carried out through seeds, seedlings, stem and root cuttings, however, it is very difficult and time consuming (Zayova et al., 2013). For that purpose, micropropagation techniques provide promising tools in the mass production of many important plant species as they offer rapid methods for the production of high quality stocks (Ben Bahri and Bettaieb, 2013). In that concern, many researchers reported the procedure of Paulownia micropropagation through shoot bud regeneration from leaf explants (Rao et al.,
1996; Ozaslan et al., 2005), root explants (Ozaslan et al., 2005), nodal and internodal explants and/or shoot tips (Castillo-Martinez et al., 2012; Ben Bahri and Bettaieb, 2013; Zayova et al., 2013; Ghatas 2016).

For the multiplication stage, axillary shoot proliferation was performed on MS medium containing cytokinins (BAP) and auxins (NAA) as PGRs (Zayova et al., 2013). It was found that the best in vitro culture conditions for plant regeneration of Paulownia elongata through internodes as obtained when applying a protocol for direct organogenesis that could use the basal MS medium with addition of different concentrations of BA and NAA, where, internodal segments showed a better induction by producing $83 \%$ explants with shoots and 1.52 shoots per explant with the $0.20 \mathrm{mg} / 1 \mathrm{NAA}$ and $4.00 \mathrm{mg} \mathrm{L}^{-1}$ BA (Castillo-Martinez et al., 2012). For root regeneration, addition of IBA to half strength MS medium was more effective than NAA and IAA achieving the highest percentage of rooting and the maximum number of roots/plant for $P$. elongata (Zayova et al., 2014).

This study aims to clarify the effect of PGRs on the ability of stem internodes of Paulownia plant to 


\section{Scientific Journal of Agricultural Sciences 3 (1): 111-118, 2021}

regenerate direct organs as well as on their morphological characteristics.

\section{MATERIALS AND METHODS}

This study was carried out on Paulownia tomentosa plant during the period from 2017 to 2019 in the Tissue Culture Lab., Department of Agricultural Botany, Faculty of Agriculture, Cairo University, Giza, Egypt.

\subsection{Establishment of sterile intact seedlings}

Ripe Paulownia tomentosa seeds (were secured from Orman Botanic Garden, Giza governorate, Egypt) were surface-sterilized through flooded in ethyl alcohol $70 \%$ for $1 \mathrm{~min}$, soaked in $0.1 \%(\mathrm{w} / \mathrm{v})$ mercuric chloride $\left(\mathrm{HgCl}_{2}\right)$ solution for 3 minutes, then rinsed for $15 \mathrm{~min}$ in sterile distilled w ater (3 times).

\subsection{Culture media and culture conditions}

The seed germination medium was tested to check its effectiveness in promoting germination and subsequent development of seeds. Basal MS (Murashige and Skoog, 1962) medium was supplemented with $30 \mathrm{~g} \mathrm{~L}^{-1}$ sucrose and $2 \mathrm{~g} \mathrm{~L}^{-1}$ gelrite. $\mathrm{pH}$ of medium was adjusted to 5.7 before autoclaving at $1.1 \mathrm{~kg} / \mathrm{cm}^{2}$ and $121^{\circ} \mathrm{C}$ for $20 \mathrm{~min}$

\subsection{Shoot regeneration}

Segments from stems derived from 45-daysold aseptic seedlings were used for shoot regeneration. Stems were cultured on MS medium supplemented with different combinations of NAA $(0.0,0.2,0.5$, and $\left.1.0 \mathrm{mg} \mathrm{L}^{-1}\right)$ and BA $\left(0.0,2.0,4.0\right.$, and $\left.8.0 \mathrm{mg} \mathrm{L}^{-1}\right)$, as well as various formulations of NAA $(0.0,0.2,0.5$, and $\left.1.0 \mathrm{mg} \mathrm{L}^{-1}\right)$ and 2ip $\left(0.0,2.0,4.0\right.$, and $\left.8.0 \mathrm{mg} \mathrm{L}^{-1}\right)$. After 3 weeks of culture, the explants began to regenerate shoots, and after 5 weeks of culture, the frequency of explants producing shoots was recorded and used to calculate the regeneration ratio.

\subsection{Root regeneration}

For root formation, in vitro regenerated welldeveloped and elongated shoots were excised and cultured on rooting medium containing half-strength MS salts with different concentrations of each of IBA $\left(0.0,0.5,1.0\right.$, and $\left.2.0 \mathrm{mg} \mathrm{L}^{-1}\right)$ and NAA $(0.0,0.5,1.0$, and $2.0 \mathrm{mg} \mathrm{L}^{-1}$ ) individually.

All cultures were incubated under controlled environmental conditions $\left(26 \pm 2^{\circ} \mathrm{C}, 3000\right.$ lux light intensity using white inflorescence tubes, $16 / 8 \mathrm{~h}$ light/dark, 60\% relative humidity).

\subsection{Data record}

Number of explants regenerated shoots per treatment was recorded and used to calculate the regeneration ratio as follows:

Regeneration $\%=$ No. of explants regenerated shoots/treatment

No. of explants/treatment

After shoot regeneration, the following data were recorded: Shoot length $(\mathrm{cm})$, Shoot fresh weight (g), Shoot dry weight (g), and after regeneration root, the following data were recorded: No. of rooted shoots, No. of roots/shoot, Average root length $(\mathrm{cm})$ and Root fresh and dry weights $(\mathrm{g})$.

\subsection{Acclimatization of plantlets}

For hardening, plantlets with developed roots were removed from jars, washed thoroughly and gently with tap water to remove the traces of agar sticking, then transplanted into polyethylene bags containing a mixture of clay, sand, and peat moss in 1:1:1 ratio, covered with transparent bags. The bags were constantly punctured and sprayed with water through a sprinkler when needed in order to gradually adapt to the external environment. This process continued for a month, after which the plants are transferred to an open field.

\subsection{Statistical Analysis}

Experiments were conducted in completely randomized block design; thirty explants were used for each treatment in 3 replicates. Calculated means were compared using least significant difference test (L.S.D) at 5\% level as described by Snedecor and Cochran (1972).

\section{RESULTS AND DISCUSSION}

\subsection{Shoot regeneration}

Results of shoot regeneration from stem internodes cultured on MS medium supplemented with different concentrations and combinations of NAA $\left(0.0,0.2,0.5\right.$, and $\left.1.0 \mathrm{mg} \mathrm{L}^{-1}\right)$ and 2ip $(0.0,2.0,4.0$, and $8.0 \mathrm{mg} \mathrm{L}^{-1}$ ) are shown in Table (1). Data clarified that the absence of grow th regulators or the addition of only auxin had led to the failure of direct shoot regeneration process, while using different combinations of the cytokinin (2ip) and the auxin (NAA) together, or the use of different concentrations of the cytokinin only, led to different ratios of direct shoot regeneration, with significant differences in most cases.

The concentration of $0.5 \mathrm{mg} \mathrm{L}^{-1} \mathrm{NAA}$ and 2 $\mathrm{mg} \mathrm{L}^{-1}$ 2ip (auxin: cytokinin ratio=1:4) recorded the 
Table 1. Effect of MS medium supplemented with NAA $\left(0.0,0.2,0.5\right.$, and $\left.1.0 \mathrm{mg} \mathrm{L}^{-1}\right)$ and $2 \mathrm{ip}(0.0,2.0,4.0$, and $\left.8.0 \mathrm{mg} \mathrm{L}^{-1}\right)$ on direct shoot regeneration of Paulownia stems.

\begin{tabular}{|c|c|c|c|c|c|}
\hline $\begin{array}{c}\mathbf{N A A} \\
\left(\mathbf{m g ~ L}^{-1}\right)\end{array}$ & $\begin{array}{c}2 \mathrm{ip} \\
\left(\mathrm{mg} \mathrm{L}^{-1}\right) \\
\end{array}$ & $\begin{array}{c}\text { Regeneration } \\
(\%)\end{array}$ & $\begin{array}{c}\text { Shoot length } \\
(\mathrm{cm})\end{array}$ & $\begin{array}{l}\text { FW } \\
(\mathrm{g})\end{array}$ & $\begin{array}{c}\text { DW } \\
(g)\end{array}$ \\
\hline 0.0 & 0.0 & $\mathbf{0}$ & $\mathbf{0}$ & $\mathbf{0}$ & 0 \\
\hline $\mathbf{0 . 0}$ & 2.0 & 85 & 9.0 & 7.2 & 0.81 \\
\hline 0.0 & 4.0 & 80 & 8.2 & 6.5 & 0.71 \\
\hline 0.0 & 8.0 & 43 & 5.5 & 4.5 & 0.42 \\
\hline 0.2 & 0.0 & $\mathbf{0}$ & $\mathbf{0}$ & $\mathbf{0}$ & $\mathbf{0}$ \\
\hline 0.2 & 2.0 & 85 & 8.4 & 7.6 & 0.75 \\
\hline 0.2 & 4.0 & 77 & 8.0 & 6.3 & 0.65 \\
\hline 0.2 & 8.0 & 77 & 7.5 & 6.1 & 0.62 \\
\hline 0.5 & 0.0 & $\mathbf{0}$ & $\mathbf{0}$ & $\mathbf{0}$ & $\mathbf{0}$ \\
\hline 0.5 & 2.0 & 95 & 10.3 & 8.1 & 0.84 \\
\hline 0.5 & 4.0 & 88 & 8.5 & 7.0 & 0.72 \\
\hline 0.5 & 8.0 & 82 & 8.2 & 6.5 & 0.66 \\
\hline 1.0 & 0.0 & $\mathbf{0}$ & $\mathbf{0}$ & $\mathbf{0}$ & $\mathbf{0}$ \\
\hline 1.0 & 2.0 & 77 & 8.0 & 6.3 & 0.71 \\
\hline 1.0 & 4.0 & 75 & 7.6 & 6.0 & 0.65 \\
\hline 1.0 & 8.0 & 50 & 6.1 & 5.8 & 0.55 \\
\hline \multicolumn{2}{|c|}{$\mathbf{L S D}_{0.05}$} & 3.3 & 0.8 & 0.5 & 0.03 \\
\hline
\end{tabular}

highest regeneration percentage, shoot length regeneration percentage, shoot length $(\mathrm{cm})$, shoot $(\mathrm{cm})$, shoot fresh and dry weights $(\mathrm{g}) ; 95 \%, 10.3 \mathrm{~cm}, \quad$ fresh and dry weight $(\mathrm{g}) ; 43 \%, 5.5 \mathrm{~cm}, 4.5 \mathrm{~g}, 0.42 \mathrm{~g}$, $8.1 \mathrm{~g}$ and $0.84 \mathrm{~g}$, respectively (Fig. $1 \mathrm{a}$ ). While the respectively (Fig. $1 \mathrm{~b}$ ). concentration of $8 \mathrm{mg} \mathrm{L}^{-1} 2$ ip only recorded the lowest

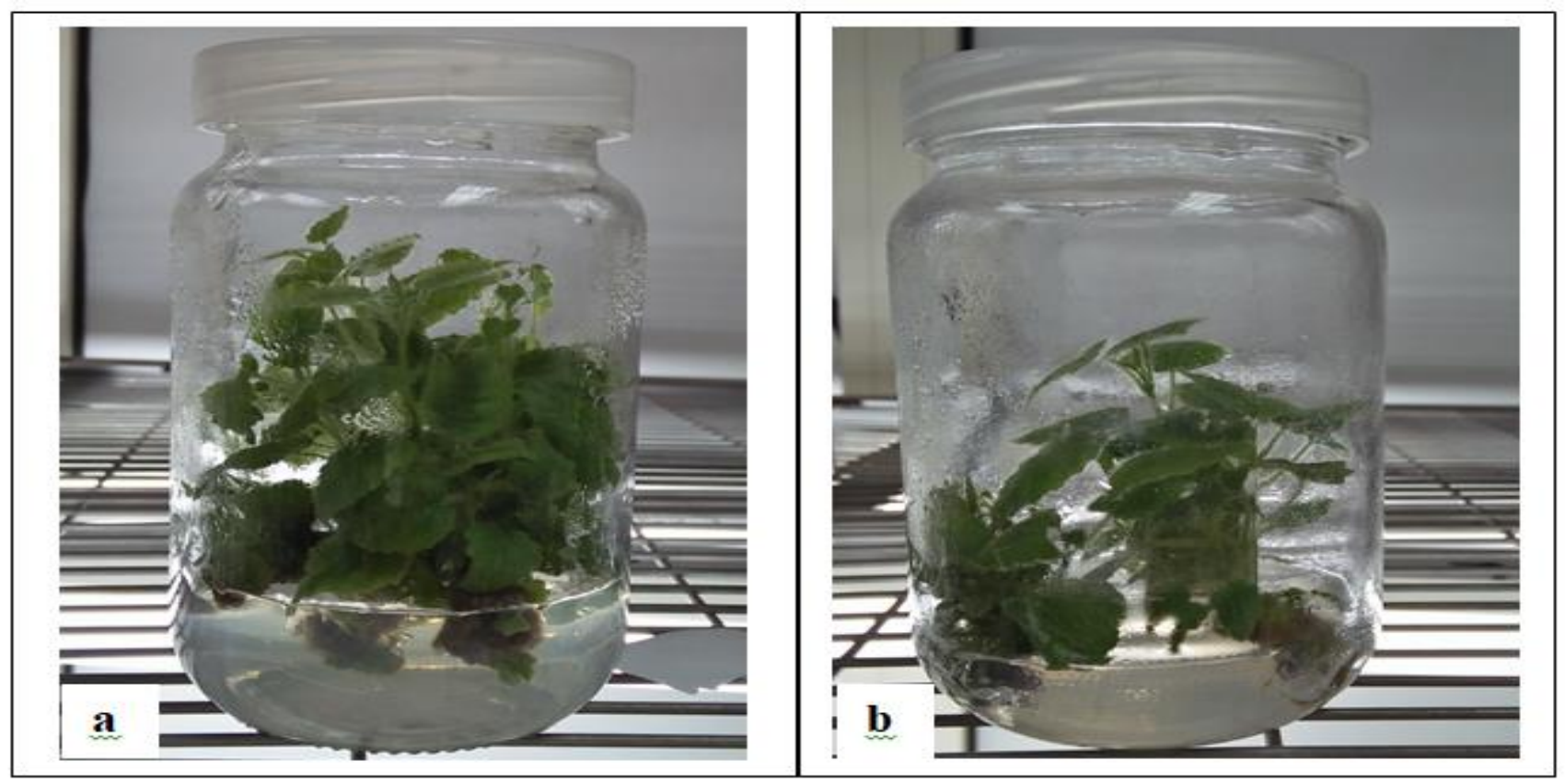

Fig. 1. Shoot regeneration from stem explants of Paulownia cultured on MS medium supplemented with (a) $0.5 \mathrm{mg} \mathrm{L}^{-1} \mathrm{NAA}+2 \mathrm{mg} \mathrm{L}^{-1} 2 \mathrm{ip}$, (b) $8 \mathrm{mg} \mathrm{L}^{-1} 2 \mathrm{ip}$. 
Table (2) presents data on stems cultured on MS medium supplemented with different concentrations and combinations of NAA $(0.0,0.2$, 0.5 , and $\left.1.0 \mathrm{mg} \mathrm{L}^{-1}\right)$ and BA $(0.0,2.0,4.0$, and $8.0 \mathrm{mg}$ $\left.\mathrm{L}^{-1}\right)$ to regenerate shoots. It was observed that the hormone free-medium or that containing only auxin did not regenerate any adventitious buds whereas various concentrations of $\mathrm{BA}$ alone or in combination with NAA mostly led to significant different ratios of direct regeneration of adventitious buds. The combination of $0.5 \mathrm{mg} \mathrm{L}^{-1} \mathrm{NAA}$ and $4 \mathrm{mg} \mathrm{L}^{-1} \mathrm{BA}$ (auxin:cytokinin ratio $=1: 8$ ) significantly scored the highest values of regeneration percentage, shoot length $(\mathrm{cm})$, shoot fresh and dry weights $(\mathrm{g}) ; 90 \%, 9.2$ $\mathrm{cm}, 9.2$ and $1.0 \mathrm{~g}$, respectively (Fig. 2a). While, the concentration of $2 \mathrm{mg} \mathrm{L}^{-1} \mathrm{BA}$ alone clearly recorded the lowest values of regeneration percentage, shoot length $(\mathrm{cm})$, shoot fresh and dry weight $(\mathrm{g}) ; 60 \%, 7.1$ $\mathrm{cm}, 6.5$ and $0.66 \mathrm{~g}$, respectively (Fig. 2b).

From the previous results (Tables, 1 and 2), it was found that auxin to cytokinin ratio played an important role in the ability of stem internodes of
Paulownia plant to regenerate shoots directly. The above mentioned results were in agreement with the results reported by Perez- and Ochoa-Alejo (1997) on Citrus reticulata, Taha et al. (2008) on Paulownia, Samantaray and Maiti (2011) on Chlorophytum arundinaceum and Castillo-Martinez et al. (2012) on Paulownia elongata. According to Samantaray and Maiti (2011), the cytokinin-auxin balance is essential for the regulation of apical dominance and some morphogenetic processes in plants $e . g$. multiplication and shoot formation. Moreover, interaction between endogenous PGRs and those present in the culture media is another factor influencing the abovementioned processes during in vitro culture. The in vitro induction of adventitious shoots is affected by various factors such as type and composition of basal medium, as well as concentration and combinations of PGRs (Feng et al., 2010). Besides, auxin-cytokinin combinations were proved to be essential in enhancing the rate of shoot bud regeneration in plants (Samantaray et al., 2009; Samantaray and Maiti, 2011).

Table 2. Effect of MS medium supplemented with NAA $(0.0,0.2,0.5$, and $1.0 \mathrm{mg}$ L-l $)$ and BA $(0.0,2.0,4.0$, and $8.0 \mathrm{mg} \mathrm{L-l}$ ) on direct shoot regeneration of Paulownia stems.

\begin{tabular}{|c|c|c|c|c|c|}
\hline $\begin{array}{c}\mathbf{N A A} \\
\left(\mathbf{m g ~ L ^ { - 1 }}\right)\end{array}$ & $\begin{array}{c}\mathbf{B A} \\
\left(\mathbf{m g ~ L ^ { - 1 }}\right)\end{array}$ & $\begin{array}{c}\text { Regeneration } \\
(\%)\end{array}$ & $\begin{array}{l}\text { Shoot length } \\
\text { (cm) }\end{array}$ & $\begin{array}{l}\text { FW } \\
\text { (g) }\end{array}$ & $\begin{array}{l}\text { DW } \\
\text { (g) }\end{array}$ \\
\hline 0.0 & 0.0 & $\mathbf{0}$ & $\mathbf{0}$ & $\mathbf{0}$ & $\mathbf{0}$ \\
\hline 0.0 & 2.0 & 60 & 7.1 & 6.5 & 0.66 \\
\hline 0.0 & 4.0 & 80 & 8.0 & 7.9 & 0.80 \\
\hline 0.0 & 8.0 & 62 & 7.5 & 7.5 & 0.70 \\
\hline 0.2 & 0.0 & $\mathbf{0}$ & $\mathbf{0}$ & $\mathbf{0}$ & $\mathbf{0}$ \\
\hline 0.2 & 2.0 & 80 & 8.5 & 7.5 & 0.75 \\
\hline 0.2 & 4.0 & 87 & 8.6 & 8.2 & 0.80 \\
\hline 0.2 & 8.0 & 83 & 7.5 & 7.1 & 0.72 \\
\hline 0.5 & 0.0 & $\mathbf{0}$ & $\mathbf{0}$ & $\mathbf{0}$ & $\mathbf{0}$ \\
\hline 0.5 & 2.0 & 85 & 8.4 & 7.6 & 0.74 \\
\hline 0.5 & 4.0 & 90 & 9.2 & 9.2 & 1.00 \\
\hline 0.5 & 8.0 & 80 & 9.0 & 8.8 & 0.85 \\
\hline 1.0 & 0.0 & $\mathbf{0}$ & $\mathbf{0}$ & $\mathbf{0}$ & $\mathbf{0}$ \\
\hline 1.0 & 2.0 & 67 & 7.5 & 6.5 & 0.68 \\
\hline 1.0 & 4.0 & 72 & 7.8 & 7.3 & 0.75 \\
\hline 1.0 & 8.0 & 71 & 7.0 & 6.8 & 0.70 \\
\hline \multicolumn{2}{|c|}{$\mathbf{L S D}_{0.05}$} & 3.8 & 0.5 & 0.2 & 0.05 \\
\hline
\end{tabular}



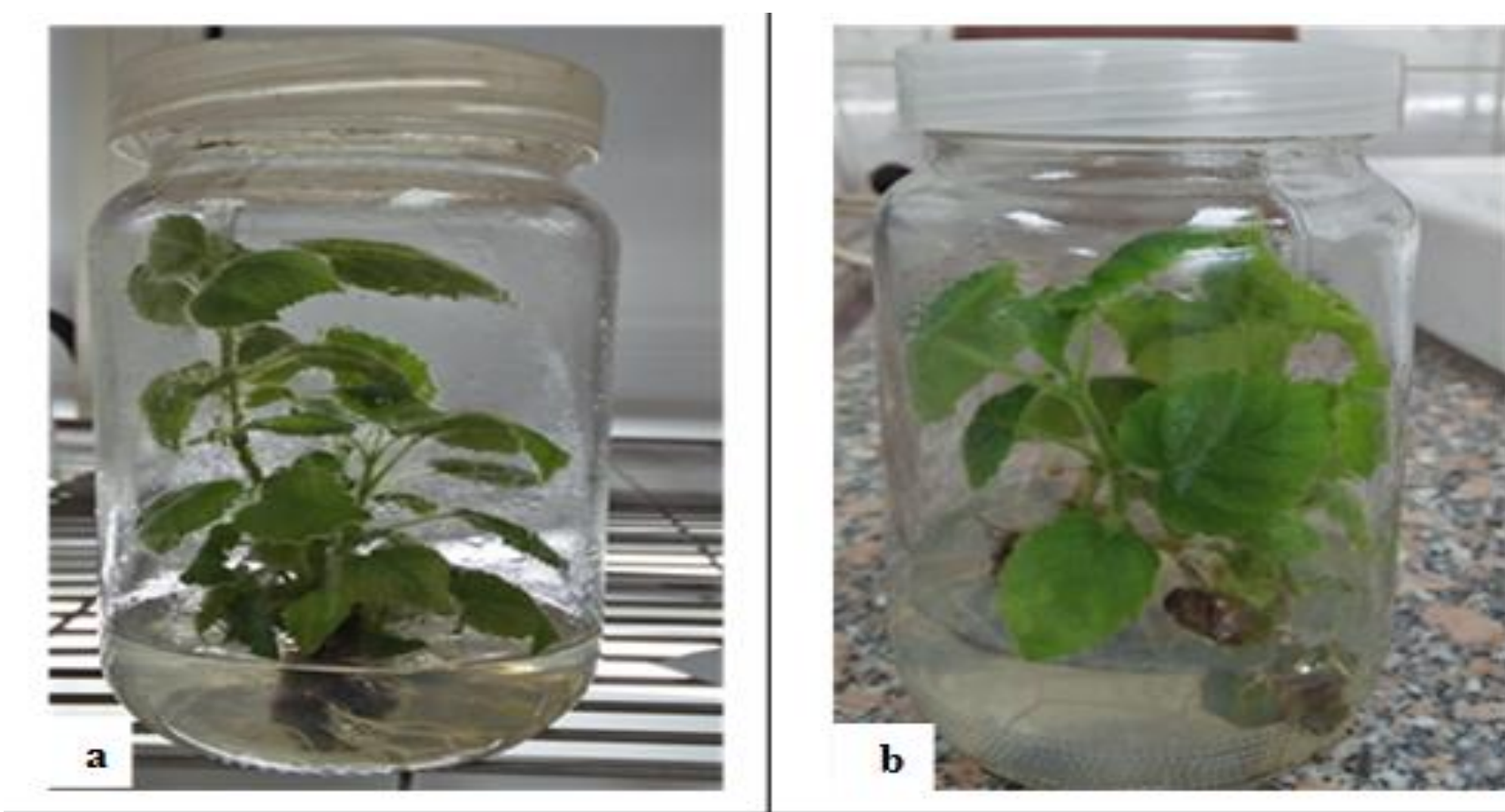

Fig. 2. Shoot production from stem explants of Paulownia cultured on MS medium supplemented with (a) $0.5 \mathrm{mg} \mathrm{L}^{-1} \mathrm{NAA}+4 \mathrm{mg} \mathrm{L}^{-1} \mathrm{BA}$, (b) $2 \mathrm{mg} \mathrm{L}^{-1}$ BA.

\subsection{Root regeneration}

Table (3) shows the data of root formation on the shoot initiated on MS medium supplemented with a combination of $0.5 \mathrm{mg} \mathrm{L}^{-1} \mathrm{NAA}$ and $2 \mathrm{mg} \mathrm{L}^{-1} 2 \mathrm{ip}$ (best shoot regeneration ratio) and cultured in halfstrength MS medium with different concentrations of NAA $\left(0.0,0.5,1.0\right.$, and $\left.2.0 \mathrm{mg} \mathrm{L}^{-1}\right)$ or IBA $(0.0,0.5$,

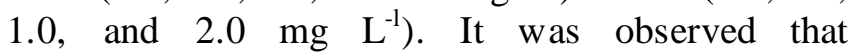
concentration of $1.0 \mathrm{mg} \mathrm{L}^{-1} \mathrm{NAA}$ or $2.0 \mathrm{mg} \mathrm{L}^{-1} \mathrm{IBA}$ gave the highest values of rooted shoots percentage, no. of roots per shoot, average root length $(\mathrm{cm})$, fresh and dry weights $(\mathrm{g})$ as follows; $(89 \%, 82 \%),(5.0,5.0)$, $(4.7,4.2 \mathrm{~cm}),(0.95,0.90$ and $0.10,0.08 \mathrm{~g})$, respectively. Whereas, using of $0.5 \mathrm{mg} \mathrm{L}^{-1} \mathrm{NAA}$ or IBA recorded the lowest values of rooted shoots percentage, no. of roots per shoot, average root length $(\mathrm{cm})$, fresh and dry weight $(\mathrm{g})$ as follows; $75 \%, 4.0$, $3.8 \mathrm{~cm}, 0.50$ and $0.04 \mathrm{~g}$, respectively, with $0.5 \mathrm{mg} \mathrm{L}^{-1}$ NAA or $66 \%, 3.0,3.2 \mathrm{~cm}, 0.50$ and $0.04 \mathrm{~g}$, respectively with $0.5 \quad \mathrm{mg} \quad \mathrm{L}^{-1} \quad$ IBA.

Table 3. Effect of auxins in half-strength MS medium on root formation of regenerated shoots of Paulownia (Shoot regeneration medium contained $0.5 \mathrm{mg}$ L-l NAA and $2.0 \mathrm{mg}$ L-l 2ip).

\begin{tabular}{|c|c|c|c|c|c|c|}
\hline $\begin{array}{l}\text { Auxin } \\
\text { Type }\end{array}$ & $\begin{array}{l}\text { Concentration } \\
\quad\left(\mathrm{mg} \mathrm{L}^{-1}\right)\end{array}$ & $\begin{array}{c}\% \text { of } \\
\text { rooted } \\
\text { shoots }\end{array}$ & $\begin{array}{c}\text { No. of roots per } \\
\text { shoot }\end{array}$ & $\begin{array}{l}\text { Average root } \\
\text { length }(\mathrm{cm})\end{array}$ & $\begin{array}{l}\text { Root FW } \\
\text { (g) }\end{array}$ & $\begin{array}{c}\text { Root DW } \\
\text { (g) }\end{array}$ \\
\hline & 0.0 & $\mathbf{0 . 0}$ & $\mathbf{0 . 0}$ & $\mathbf{0 . 0}$ & 0.00 & 0.00 \\
\hline \multirow[t]{4}{*}{ NAA } & 0.5 & 75 & 4.0 & 3.8 & 0.50 & 0.04 \\
\hline & 1.0 & 89 & 5.0 & 4.7 & 0.95 & 0.10 \\
\hline & 2.0 & 80 & 5.0 & 4.5 & 0.80 & 0.09 \\
\hline & 0.0 & 0.0 & 0.0 & 0.0 & 0.00 & 0.00 \\
\hline \multirow[t]{4}{*}{ IBA } & 0.5 & 66 & 3.0 & 3.2 & 0.50 & 0.04 \\
\hline & 1.0 & 71 & 4.0 & 3.8 & 0.73 & 0.06 \\
\hline & 2.0 & 82 & 5.0 & 4.2 & 0.90 & 0.08 \\
\hline & $\mathbf{L S D}_{0.05}$ & 3.1 & 1.2 & 0.2 & 0.08 & 0.02 \\
\hline
\end{tabular}


Data in Table (4) clarifies the root formation initiated on shoots by using MS medium with addition of a combination of $0.5 \mathrm{mg} \mathrm{L}^{-1} \mathrm{NAA}$ and $4.0 \mathrm{mg} \mathrm{L}^{-1}$ BA (second best shoot regeneration ratio) and cultured in half-strength MS medium with different concentrations of NAA $\left(0.0,0.5,1.0\right.$, and $\left.2.0 \mathrm{mg} \mathrm{L}^{-1}\right)$ or IBA $\left(0.0,0.5,1.0\right.$, and $\left.2.0 \mathrm{mg} \mathrm{L}^{-1}\right)$. The results obtained showed that the concentration of $1.0 \mathrm{mg} \mathrm{L}^{-1}$ NAA or $2.0 \mathrm{mg} \mathrm{L}^{-1}$ IBA gave the highest records of rooted shoots percentage, no. of roots per shoot, average root length $(\mathrm{cm})$, fresh and dry weights $(\mathrm{g})$ as their values were; $(78 \%, 73 \%),(4.0,3.0),(3.9,3.8$ $\mathrm{cm}),(0.86,0.77$ and $0.09,0.08 \mathrm{~g})$, respectively. On the other side, using of $0.5 \mathrm{mg} \mathrm{L}^{-1} \mathrm{NAA}$ or IBA recorded the lowest records of rooted shoots percentage, no. of roots per shoot, average root length $(\mathrm{cm})$, fresh and dry weight $(\mathrm{g})$ as their values were; $70 \%, 3.0,3.2 \mathrm{~cm}, 0.45$ and 0.04 , respectively, with 0.5 $\mathrm{mg} \mathrm{L}^{-1} \mathrm{NAA}$ or $65 \%, 3.0,3.4 \mathrm{~cm}, 0.65$ and $0.06 \mathrm{~g}$, respectively, with $0.5 \mathrm{mg} \mathrm{L}^{-1} \mathrm{IBA}$.
From the results of Tables 3 and 4, it is clear that the ratio of auxin to cytokinin in the direct shoot regeneration medium had a clear effect on its response to the type and level of auxin used in the rooting medium. The previous results were in agreement with those obtained by many researchers. Most authors indicated that IBA was the best auxin in root induction of Paulownia (Rout et al., 2001; Ben Bahri and Bettaieb, 2013; Shtereva et al., 2014; Zayova et al., 2014) with a similar result concluded by Samantaray and Maiti (2011) on Chlorophytum arundinaceum. On the other hand, Taha et al. (2008) reported that NAA at 0.5 and $1 \mathrm{mg} \mathrm{L}^{-1}$ were more effective in terms of rooting percentage and number of roots per shootlet of Paulownia kowakamii, while Feng et al. (2010) deduced that half strength MS medium supplemented with NAA was optimal for rooting of jujube 'Huizao'. In conclusion, the presence of an auxin in the culture medium is essential for root induction.

Table 4. Effect of auxins in half-strength MS medium on root formation of regenerated shoots of Paulownia (Shoot regeneration medium contained $0.5 \mathrm{mg}$ L-1 NAA and $4.0 \mathrm{mg}$ L-1 BA).

\begin{tabular}{|c|c|c|c|c|c|c|}
\hline $\begin{array}{c}\text { Auxin } \\
\text { Type }\end{array}$ & $\begin{array}{c}\text { Concentration } \\
\left(\mathbf{m g ~ L}^{-1}\right)\end{array}$ & $\begin{array}{l}\% \text { of rooted } \\
\text { shoots }\end{array}$ & $\begin{array}{l}\text { No. of roots } \\
\text { per shoot }\end{array}$ & $\begin{array}{l}\text { Average root } \\
\text { length }(\mathrm{cm})\end{array}$ & $\begin{array}{c}\text { Root FW } \\
\text { (g) }\end{array}$ & $\begin{array}{c}\text { Root DW } \\
(\mathrm{g})\end{array}$ \\
\hline & $\mathbf{0 . 0}$ & $\begin{array}{l}0.0 \\
\end{array}$ & $\mathbf{0 . 0}$ & $\begin{array}{l}0.0 \\
\end{array}$ & 0.00 & 0.00 \\
\hline \multirow[t]{4}{*}{ NAA } & 0.5 & 70 & 3.0 & 3.2 & 0.45 & 0.04 \\
\hline & 1.0 & 78 & 4.0 & 3.9 & 0.86 & 0.09 \\
\hline & 2.0 & 75 & 3.0 & 3.5 & 0.65 & 0.06 \\
\hline & 0.0 & 0.0 & 0.0 & 0.0 & 0.00 & 0.00 \\
\hline \multirow[t]{3}{*}{ IBA } & 0.5 & 65 & 3.0 & 3.4 & 0.65 & 0.06 \\
\hline & 1.0 & 67 & 3.0 & 3.5 & 0.75 & 0.07 \\
\hline & 2.0 & 73 & 3.0 & 3.8 & 0.77 & 0.08 \\
\hline $\mathbf{L S D}_{0.05}$ & & 4.3 & 0.9 & 0.2 & 0.10 & 0.02 \\
\hline
\end{tabular}

\subsection{Acclimatization of plantlets}

The well rooted shoots of Paulownia (Fig. 3a) were transferred ex vitro to acclimate to the natural weather conditions in polyethylene bags containing a mixture of clay, sand, and peat moss in 1:1:1 ratio (Fig. $3 \mathrm{~b}$ ), more than $90 \%$ of the acclimatized plants successfully survived (Fig. 3c). Peat-soil mixtures were found effective for the acclimatization of Paulownia rooted shoots (Ben Bahri and Bettaieb, 2013; Zayova et al., 2014).

\section{CONCLUSION}

Due to difficulty of propagating Paulownia by seeds, it is possible to obtain it through tissue culture after acclimatization. It could be concluded from the previous results that, Paulow nia can be regenerated via in vitro culture using MS-medium supplemented with a combination of $0.5 \mathrm{mg} \mathrm{L}^{-1} \mathrm{NAA}$ and $2 \mathrm{mg} \mathrm{L}^{-1} 2$ ip or $0.5 \mathrm{mg} \mathrm{L}^{-1} \mathrm{NAA}$ and $4 \mathrm{mg} \mathrm{L}^{-1} \mathrm{BA}$. In vitro root regeneration was achieved at $1.0 \mathrm{mg} \mathrm{L}^{-1} \mathrm{NAA}$ or 2.0 $\mathrm{mg} \mathrm{L}^{-1}$ IBA, each individually.

\section{ACKNOWLEDGEMENT}

The researchers would like to express their sincere grateful to the Prof. Dr. Atef Z. Sabh (Agricultural Botany Dept., Faculty of Agriculture, Cairo University, Giza, Egypt) for his full support to achieve this work. 


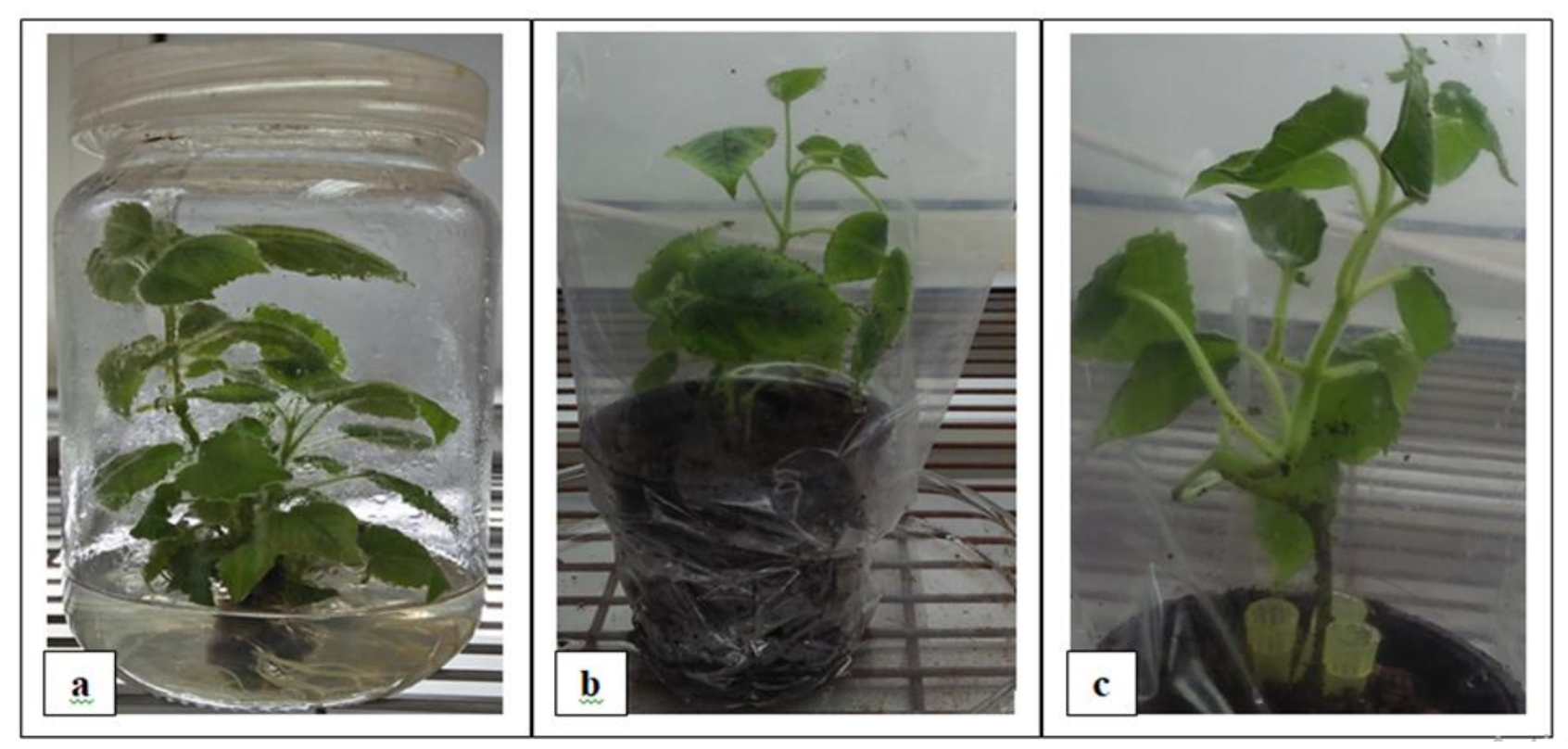

Fig. 3. Acclimatization stages of plantlets, (a) Root formation, (b) ex vitro acclimatization, (c) Paulownia tomentosa plantlets under natural conditions.

\section{REFERENCES}

Ben Bahri N, Bettaieb T(2013). In vitro propagation of a forest tree Paulownia tomentosa (Thunb.) Steud. A valuable medicinal tree species. Albanian J. Agric. Sci., 12(1): 37-42.

Castillo-Martínez RC, Gutiérrez-Espinosa MA, Buenrostro-Nava MT, Alcalá VMC, Iñiguez JC (2012). Regeneration of Paulownia elongata Steud Plants by Direct Organogenesis. Rev. Mex. Cien. For 3(10): 41-49.

El-Homosany A, Noor El-Deen TM (2019). In vitro storage of Paulow nia tomentosa. Scientific J. Flowers \& Ornamental Plants., 6(3): 139-149.

Feng JC, Yu XM, Shang XL, Li JD, Wu YX (2010). Factors influencing efficiency of shoot regeneration in Ziziphus jujuba Mill.'Huizao'. Plant Cell, Tissue and Organ Culture (PCTOC), 101(1): 111-117.

Ghatas Y (2016). Employment of tissue culture techniques in improvement propagation of Paulownia tomentosa plant. J. of Plant Production, 7(6): 619-625. Murashige T, Skoog F (1962). A revised medium for rapid growth and bio assays with tobacco tissue cultures. Physiol. Plant., 15(3): 473-497.

Ozaslan M, Can C, Aytekin T. (2005). Effect of explant source on in vitro propagation of Paulownia tomentosa Steud. Biotechnology \& Biotechnological Equipment, 19(3): 20-26.

Pérez-Molphe-Balch E, Ochoa-Alejo N (1997). In vitro plant regeneration of Mexican lime and mandarin by direct organogenesis. HortScience, 32(5): 931-934.
Puxeddu M, Marras G, Murino G (2012). Paulownia tree planting in Sardinia (Italy) and its evaluation for agroforestry systems and sustainable land use. J. Environ. Sci. Eng. Technol., B, 1(10B): 1192-1195.

Rao CD, Goh CJ, Kumar PP (1996). High frequency adventitious shoot regeneration from excised leaves of Paulownia spp. cultured in vitro. Plant Cell Reports, 16(3-4), 204-209.

Rout GR, Reddy GM, Das P (2001). Studies on in vitro clonal propagation of Paulownia tomentosa Steud. and evaluation of genetic fidelity through RAPD marker. Silvae Genet., 50(5-6), 208-211.

Samantaray S, Kumar S, Maiti S (2009). Direct shoot regeneration from immature inflorescence cultures of Chlorophytum arundinaceum and Chlorophytum borivilianum. Biologia, 64(2):305-309. Samantaray S, Maiti S (2011). Factors influencing rapid clonal propagation of Chlorophytum arundinaceum (Liliales: Liliaceae), an endangered medicinal plant. Revista de biologia tropical, 59(1), 435-445.

Shtereva L, Vassilevska-Ivanova R, Karceva T, Kraptchev B (2014). Micropropagation of six Paulownia genotypes through tissue culture. J. Cent. Eur. Agric., 15(4), 147-156.

Snedecor GW, Cochran WG (1972). Statistical methods 6th ed. Iowa State Collage, Press, Amer. Iowa, U.S.A. 


\section{Scientific Journal of Agricultural Sciences 3 (1): 111-118, 2021}

Taha LS, Ibrahim SMM, Farahat, MM (2008). A Micropropagation Protocol of Paulownia kowakamii through in vitro culture technique. Aust. J. Basic \& Appl. Sci., 2(3): 594-600.

Zayova E, Petrova M, Vasilevska R, Stoeva D, Krapchev B (2013). A tissue culture technique for propagation of Paulownia elongata tree. Biological Diversity and Conservation 6 (3):1-5.

Zayova E, Petrova M, Dimitrova L, VasilevskaIvanova R, Stoeva D (2014). Effect of different auxins on in vitro rooting of Paulownia elongata propagated plants. Genetics \& Plant Physiology, 4(34), $155-162$.

\section{الملخص العربي}

تأثير منظمات النمو النباتية على التخلق المباشر للأعضاء معمليا في نبات البولونيا

$$
\begin{aligned}
& \text { زينب قاسم طه و انجي علاء سليم }
\end{aligned}
$$

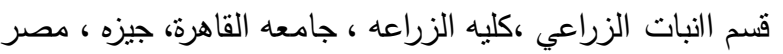

تم إكثار نبات البولونيا في معمل زراعة الانسجة التابع لقم النبات الزراعي لمعرفة تأثثر منظمات النمو على قدرة سلاميات ساق النبات على لئ

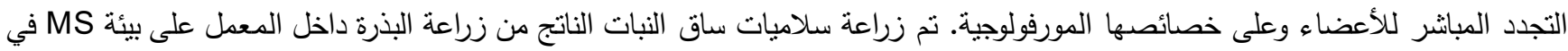
وجود توليفات مختلفة من منظمات النمو (نفتالين حامض الخليك مع البنزيل أدينين وأيضا مع ب أيزو بنتينايل أدينين).

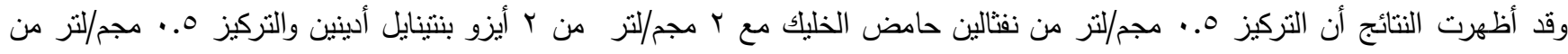
نفتالين حامض الخليك مع ء مجم/لتر من البنزيل أدينين قد أعطت أعلى نسبة تجدد مباشر للأعضاء وكذللك طول المجموع الخضري (سم) والوزن

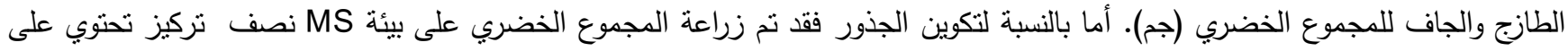
تركيزات مختلفة من نفتالين حامض الخليك و إندول البيوتريك (كلا على حده). وقد لوحظ أن استخدام تركيز ..1 مجم/لتز من نفتالين حامض الخليك أو نركيز r مجم/لتز من إندول حامض البيوتريك قد نتج عنه أعلى نسبة لتكوين الجذور وعدد الجذور وطول الجذور (سم) والأوزان الطازجة والجافة للجذور (جم). الكلمات المفتاحيه : النظلق المبانشر للاعضاء ،منظمات النمو النباتيه ، الخصائص المورفولوجيه ، نبات البولونيا ،سلاميات الساق 